\title{
A book burner or not? History and myth: Revisiting al-Qāọī 'lyāọ and the controversies over al-Ghazālī in the Islamic West
}

\author{
NORA S. EGGEN (University of Oslo, Norway)
}

\begin{abstract}
A number of scholars in the medieval Islamic West engaged with the work of Abū Hiāmid al-Ghazāli (d. 505/1111), and he was both celebrated and criticised. Among the scholars who are allotted with a prominent role in the controversies around his work, is the Ceutan judge and scholar al-Qāḍi 'Iyāọ (d. 544/1149). To some extent, his role in the controversies which allegedly resulted in the burning of some of al-Ghazālī's books, has become a significant element in 'Iyāḍ's intellectual and historical biography and in construing him as a somewhat fanatic defender of a particular scholarly tradition, the Mālikī tradition, and a particular political order, the Almoravid dynasty. Although 'Iyāḍ's own writings clearly position him within the Mâlikī scholarly tradition and although historical evidence clearly suggests that he sided with the Almoravids in the Almoravid-Almohad conflict of the early twelfth century, the image of a fierce fanatic and a book burner seems to stem from a later date. The earliest traceable source for this image is an anecdote in al-Sha'rān̄̄'s (d. 973/1565) Lawāqih al-anwār. In other, later sources additional and partly different images of 'Iyạ̣̄ are construed, motivated by the controversies over al-Ghazālī. However the basis for these images is likewise neither to be found in 'Iyāḍ's own work nor in available historical sources earlier than al-Sha' rānī.
\end{abstract}

Key words: al-Qāḍ̄i 'Iyāẹ, Abū Ḥāmid al-Ghazālī, Almoravids, Almohads, historiography, intellectual history, book burning

\section{Introduction}

Abū Ḥāmid al-Ghazālî̀s (d. 505/1111) work, and in particular his magnum opus Ihyyā 'ulüm al-dīn, met a variety of responses in the early twelfth-century Almoravid Islamic West. Several Andalusian and North-African scholars were involved in the discussions about this work, taking different positions. ${ }^{1}$ The official attitude towards al-Ghazālī changed from a more favourable view during Yūsuf Ibn Tāshfīn's reign (r. 453-500/10611106) to a mixed and even negative view during 'Alī Ibn Yūsuf's reign (r. 500-537/1106-

1 Delfina SERrano RuAno, "Why Did the Scholars of al-Andalus Distrust al-Ghazālī? Ibn Rushd alJadd's Fatwā on Awliyāa Allāh," Der Islam, 83.1 (2006): 137-156; Janina M. SAFRAN, "The politics of book burning in al-Andalus," Journal of Medieval Iberian Studies, 6.2 (2014): 148-168, 155-162. See also a summarized discussion in Yousef CASEWIT, The Mystics of al-Andalus: Ibn Barrajan and Islamic thought in the twelfth century, Cambridge: Cambridge University Press, 2017: 50-56. 
1143). ${ }^{2}$ According to some sources, the controversies eventually led to official condemnation of the Ihya $\vec{a}^{3}$, and two rounds of banning and burning, or issuing of orders to burn the book, first under 'Alī Ibn Yūsuf in 503/1109 (alternative dates given are 500/1106, or 509/1116), and then under Tāshfīn Ibn 'Alī (r. 537-539/1143-1145) in 538/1143. ${ }^{3}$

The historical, scholarly and political circumstances of the controversies are far from clear. ${ }^{4}$ Neither is the position nor the possible role the celebrated scholar and judge of Ceuta, Abū 'l-Faḍl 'Iyāẹ Ibn Mūsà, known as al-Qāḍī 'Iyāọ (d. 544/1149), may have had in it. However, 'Iyậ̂ is often mentioned as one supporting the condemnation and burning or even as issuing a fatwà on the issue. While scholars have expressed doubts about this being a historical fact, ${ }^{5}$ the alleged incidents continue to form a part of the interpretative frame for 'Iyāḍ's life and work. ${ }^{6}$ Thus it has become a significant element of the historiography of this particular scholar as well as this particular period of the intellectual history of the Islamic west. ${ }^{7}$ In this paper I revisit this historiography to discuss two questions: What do

2 Rachid El Hour, "The Andalusian Qāḍi in the Almoravid Period: Political and Judicial Authority," Studia Islamica, 90 (2000): 67-83, 73. Abū Muhammad Ibn al-'Arabī (d. 492/1099), Abū Bakr Ibn al'Arabī's (d. 543/1148) father, was commissioned by Yūsuf Ibn al-Tāshfīn to travel to Baghdad to seek the formal recognition of the 'Abbāsid caliph. Abū Muḥammad also carried a letter asking al-Ghazālī for a fatwà allowing Yūsuf to intervene in al-Andalus. In a fatwà and a letter addressed to Yūsuf, alGhazālī formally endorsed Yūsuf's legitimate leadership in the West under the title amīr al-muslimīn wa-nāșir al-dīn al-qä̉im bi-da'wat amīr al-mu'minīn. The letter has been edited by E. LÉVI-PROVENÇAL in "Le titre souverain des Almoravides et sa légitimation par le califat 'abbaside," Arabica, 2 (1955): 265-280; see both documents translated into Spanish in María J. VIGUERA, "Las cartas de al-Gazālī y al-Ṭurț̄̄ši al soberano almorávid Yūsuf b. Tāšufīn," al-Andalus, 42.2 (1977): 341-374, 353-361. LéviProvençal remarks (p. 279, with reference to the anonymous chronicle al-Hulal al-mawshiyya) that in 512/1117-8 a corresponding formal investiture was granted from the same 'Abbāsid caliph al-Mustaẓhir (r. 487-512 /1094-1118) to 'Alī.

3 Maribel FIERro, "Opposition to Sufism in al-Andalus," in Islamic Mystisicm Contested: Thirteen Centuries of Controversies and Polemics, 174-206, eds. Frederick DE JONG and Bernd RADTKE, Leiden: Brill, 1999: esp. 185-186; 191-196; SAFRAN, “The politics of book burning,” 155-162.

4 Al-Ghazālī adressed these issues in his Kitāb al-imlā' fì ishkālāt al-ihya $\bar{a}^{\text {, }}$, where he refers to people groundlessly forbidding the reading of $I h y \bar{a}$ ' without really having understood it (bi-mujarradi 'l-hawà 'alà ghayri 'lbașìra). However, he does not mention any names. (Printed in Abū Hāmid Muhammad Ibn Muhammad alGHAZĀLĪ, Ihyā' 'ulūm al-dīn, 5 vols., Beirut: Dār al-Kutub al-'Ilmiyya, 2001, V: 13-41, 13). See also Kenneth GARDEN, The First Islamic Reviver: Abū Hāmid Al-Ghazālī and His Revival of the Religious Sciences, Oxford: Oxford University Press, 2014: 149-152.

5 The allegation was questioned already by Duncan B. MACDONALD on account of lacking historical evidence as well as chronological inconsistencies ("The Life of al-Ghazzālī, with Especial Reference to His Religious Experiences and Opinions," Journal of the American Oriental Society, 20 (1899): 71132). Sa'd GHRĀB characterized the allegation as a mere fantasy (khayāl) ("Hawla iḥrāq al-murābiṭīn liIhyā' al-Ghazālī," Actas del IV Coloquio Hispano-Tunecino, Madrid: Instituto Hispano-Árabe de Cultura, 1983: 133-163, 154). For a recent sceptic, see Camilo GómEZ-RIVAS, "Qāọ̄i 'Iyāọ̣ (d. 544/1149)," in Islamic Legal Thought: A Compendium of Muslim Jurists, ed. Oussama ARABI, David Stephan Powers, and Susan Ann SPectorsky, Leiden: Brill, 2013: 323-338, 327; Camilo GómeZRIVAS, Law and the Islamization of Morocco under the Almoravids: The Fatwās of Ibn Rushd al-Jadd to the Far Maghrib, Leiden: Brill, 2014: 119.

6 Most recently in CASEWIT, The Mystics of al-Andalus, 52.

7 On the social, intellectual and political life in the Almoravid and Almohad periods in Islamic West, see the excellent recent study: Amira K. BENNISON, The Almoravid and Almohad Empires, Edinburgh: 
historical sources tell us about the factuality of 'Iyāḍ's alleged involvement in these controversies? And how, when and why was this involvement first construed and established?

The allegations put forward in recent years typically refer directly or indirectly to two secondary sources from the late $1990 \mathrm{~s}^{8}$ In the following I take these two references as a starting point to revisit the historical and biographical sources on these controversies and incidents, in search for references to 'Iyâd. In addition I examine the possible impact of individuals in 'Iyāḍ's own network who voiced opinions on or had relationships with alGhazāli. ${ }^{9}$ I argue that the details of the matter provide material for a necessary questioning of a simplistic historiography of the intertwined intellectual and political situation in the early twelfth-century Almoravid Islamic West. The material also sheds some light on how this relatively modest scholar from the Islamic West later has been made to play a role in very different geographical, temporal, and cultural contexts.

\section{Al-Zabīdī's reference to the burning of the Ihyā'}

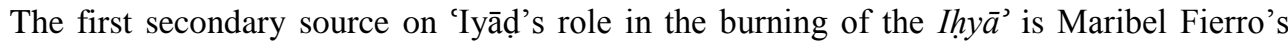
reference to Murtaḍà al-Zabīī̄'s (d. 1205/1790) commentary Ithấf al-sāda al-muttaqīn bi-

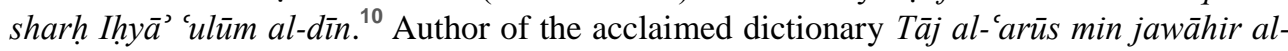
$q \bar{a} m \bar{u} s$, this Indian philologist, who studied in Yemen and ended his life in Egypt, wrote a voluminous commentary on al-Ghazālī's $I h y \bar{a}$ ' in which he gathered different kinds of available material. ${ }^{11}$ After praising the $I h y \bar{a}^{2}$ for its extraordinary way of combining transmitted knowledge with reasoning, and thinking with tradition (naql and nazar, fikr and

Edinburgh University Press, 2016.

8 In her articles from 1997 and 1999, Maribel Fierro held that 'Iyāḍ, as well as Ibn Hirzihim (d. 559/ 1165 ), issued fatwàs in favour of burning the Ihya ' (FIERRO, "Opposition to Sufism," 18 and footnote 53; Maribel FIERRO, "La religión”, in El retroceso territorial de al-Andalus. Almorávides y almohades: Siglos XI al XIII, 483-495, ed. María Jesús VigeruA MolínS, Madrid: Espasa Calpe, 1997: 483-95, 485, footnote 19). Delfina Serrano Ruano held in a 1999 article, and confirmed in 2006, that 'Iyāḍ was involved in the burning of al-Ghazāli's work (SERRANO, "Why Did the Scholars of al-Andalus Distrust al-Ghazālī?," 138, footnote 10; Delfina SERRANO, "Los Banū 'Iyāḍ (de la caída del imperio almorávid a la instauración de la dinastía nazarí)," in Biografías almohades I, 351-406, eds. María Luisa ÁvILA NAVARro and María Isabel FIERro Bello, Madrid: Consejo Superior de Investigaciones Científicas, 1999. Muḥammad Ibn Sharīfa mentioned in his 1982 edition of Muḥammad Ibn 'Iyāḍ's biography of his father, the names al-Zabīdī, Ibn 'Imād and al-Sha'rānī as the sources for the allegations that 'Iyāḍ had

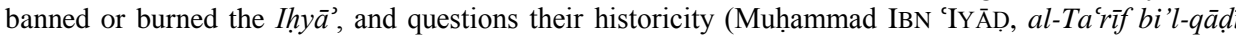
'Iyāẹ, ed. Muhammad IBN SHARĪFA, Rabat: Wizārat al-Awqāf wa'l-Shu’ūn al-Islāmiyya, 1982: 107, footnote 274).

9 'Iyāọ wrote about his network in his fahrasa, al-Ghunya (al-QĀḌ̄ 'IYĀḌ, al-Ghunya: Fihrist shuyūkh alQāộ̀ 'Iyāẹ, ed. Māhir Zuhayr JARRĀR, Beirut: Dār al-Gharb al-Islāmī, 1982, completed one year before he died.

10 FIERro, “Opposition to Sufism," 18 and footnote 53; FiERro, "La religión," 485, footnote 19.

11 Murtaḍà al-ZABĪDĪ, Ithậf al-sāda al-muttaqīn bi-sharh Ihyyà' 'ulūm al-dīn, 13 vols., Miṣr: al-Maṭba'a almaymaniyya, 1311 [=1893-4], I: 27. On the Ithāf, see Stefan REICHMUTH, The World of Murtaḍa alZabīdī (1732-91): Life, Networks and Writings, Cambridge: E.J. Gibb Memorial Trust, 2009: 269-334. 
athar), al-Zabīdī reports almost verbatim an anecdote from al-Sha'rānī's (d. 973/1565) Lawāqiḥ al-anwār via al-Munāwī (d. 1031/1621).

'Abd al-Wahhāb al-Sha'rān̄̄ was an Egyptian Shāfí̄̄ jurisprudent and șūfì. ${ }^{12}$ His Lawāqih al-anwār al-qudsiyya fi manāqib al-'ulamā' wa'l-șūfiyya, also known as alTabaqāt al-kubrà, is a biographical dictionary. In his introduction to this work, al-Sha'rānī asserts that al-tașawwuf is a discipline of knowledge in its own right ( ${ }^{i l m}$ mustaqill, p. 12), and that he collected these biographies of the great men of this discipline to counter the condemnation they met (inkār, p. 9). Referring to a saying from al-Shāfi ${ }^{\prime} \overline{1}$, he holds that such condemnation is a sign of hypocrisy (nifāq, p. 30); then he goes on to tell a number of stories of different kinds of attacks on scholars of the discipline of tașawwuf, which exemplify such condemnation. One of these stories reports that al-Ghazāli was accused of stepping out of the boundaries of religion (aftaw bi-takfir al-imām al-Ghazālì, p. 34), and that the Ihyya $\vec{a}^{\prime}$ was burned. Al-Sha'rānī does not specify the year of these events, so we do not know whether he is referring to the first, second or both incidents mentioned above. AlSha'rānī states:

Among the group that condemned (ankara) al-Ghazālī and issued a fatwà about burning his book were al-Qāḍ̄i 'Iyāḍ and Ibn Rushd. When this reached al-Ghazāīi, he cursed the judge ['Iyâd,], who died suddenly in his bath the same day. It has been said that al-Mahdī [see below] was the one who ordered that he ['Iyāḍ] should be killed after people in his town accused him of being a Jew on account of him not coming out on Saturdays because he was busy working on the Shifä'. However, it was because of al-Ghazālī's curse that al-Mahdī killed him. ${ }^{13}$

The Mahdī referred to must be Ibn Tūmart (d. 525/1130), the founder of the Almohad movement in the first half of the twelfth century in the Maghrib, who declared himself or was declared by his followers to be al-mahdī al-ma' $\bar{u} m$ and al-imām al-ma șīm. ${ }^{14}$ The historical circumstances of the relationship between Ibn Tūmart and al-Ghazālī are not clear, but Ibn Tūmart seems to have had a favourable view of al-Ghazālī and had allegedly studied with him in the East. ${ }^{15}$

12 'Abd al-Wahhāb al-SHA'RĀNĪ, Al-Ṭabaqāt al-kubrà (= Lawāqih al-anwār al-qudsiyya fì manāqib al'ulamā’ wa'l-șüfiyya), ed. Aḥmad 'Abd al-Raḥmān al-SĀYıH and Tawfīq 'Alī WAHBA, 2 vols., Cairo: Maktabat al-Thaqāa al-Dīniyya, 2005, I: 34. On al-Sha rān̄̄, see Michael WINTER, Society and Religion in Early Ottoman Egypt: Studies in the Writings of 'Abd al-Wahhāb al-Sha'rānī, New Brunswick: Transaction Books, 1982.

13 Al-SHA'RĀNĪ, al-Ṭabaqāt al-kubrà, I: 34 .

14 The sources are not decisive on the question of who declared him Mahdī, but upon his death it was a well-established denomination for him ([IBN TŪMART, Kitāb a'azz mā yuțlab,] Le livre de Mohammed Ibn Toumert, ed. I. GolDZIHER, Alger: Imprimerie Orientale Pierra Fontana, 1903: 246, cf. Allen J. FrOMHERZ, The Almohads: The Rise of an Islamic Empire, London \& New York: I.B. Tauris, 2010 237-238; Mercedes GARCíA-ArenAl, Messianism and Puritanical Reform: Mahdīs of the Muslim West, Leiden: Brill, 2006: 180-184).

15 Madeleine Fletcher has reviewed the sources for the possible interviews between Ibn Tūmart and alGhazālī, but remarks that most importantly "Ibn Tūmart's written legacy reveals that the major elements: rational theology, religious reform and sufism, were principles he shared with al-Ghazālì," and, as events testify, "In the mind of the Almoravid ruling group, the Almohads were doctrinally

jais • 18 (2018): 87-109 
When considered as an historical account, there are obvious discrepancies with regard to al-Sha 'rānī's chronology of the events, as al-Ghazālī died in 505/1111, Ibn Tūmart in 525/1130 and 'Iyāḍ in 544/1149. Al-Ghazālī may have heard about the first burning in 503/ 1109 , but it is hardly likely that the then twenty years young 'Iyāḍ in Ceuta had any role in that. The second incident took place in 538/1143, and although it is not possible to date 'Iyāḍ's prophetological work al-Shifā' bi-ta'rîf huqūq al-muștafà decisively, it may very well have been composed between 1137 and 1145, when 'Iyâḍ did not have any public duties. ${ }^{16}$ However, this second incident took place long after both al-Ghazālì and Ibn Tūmart had died. On the other hand, the account may be understood to refer to the extraordinary visionary powers attributed to Ibn Tūmart, which could suggest an early Almohad source for the story. Although the available Almohad sources do mention the burning, as we will see, they do not present us with these miraculous stories. These are, on the contrary, found in later sources seeking to distinguish al-Ghazālī.

Al-Sha'rān̄̄ was a theologian and a jurist, and above all a mystic highly influenced by the in his time already classical șu $f \grave{\imath}$ work $I h y \bar{a} \cdot{ }^{17}$ He apparently did not consider himself a historian, and his biographical dictionary has been described as inaccurate. Michael Winter holds that to al-Sha'rānī "people and events per se had little meaning. For him they became significant only when they could teach a religious or moral lesson." ${ }^{18}$ It is thus quite possible that the anecdote he told about 'Iyāọ has little or no historical value. Moreover, it is not included in one of the bibliographical entries, but in the general introduction. That does, however, not explain how or why 'Iyāḍ's name came to be attached to it. 'Iyāḍ was a wellknown scholar in the East: as a historian of the Mālikī intellectual tradition with his biographical dictionary Tartīb al-madārik, ${ }^{19}$ as a scholar of hadīth with his commentaries and theoretical works, ${ }^{20}$ and not least as the author of the Shifä ' which reached a variety of

associated with al-Ghazālī," (Madeleine FLETCHER, "Ibn Tūmart's teachers: the relationship with alGhazālī," al-Qanțara, 18.2 (1997): 305-330, 326). The only remark Fletcher has on 'Iyāẹ in this connection is an unsubstantiated claim (p. 316) that "Cadi 'Iyā of Ceuta, who rebelled against the Almohads, claims that the weirdly harsh judgements Ibn al-'Arabī handed down were the cause of his removal from office. Cadi 'Iyāḍ distills all possible negative aspects of that situation and others, making an implication of homosexuality in quoting his poetry and saying that his hadiths were not accepted by someone."

16 See Nora S. EGGEN, "In defence of the Prophet, and of scholarly tradition: al-Qāḍ̂̄ 'Iyāḍ's al-Shifä' bita'rîf huqūq al-muștafà - The Healing in Knowing the Rights of the Chosen One," in Freedom of Expression in Islam: Challenging Apostasy and Blasphemy Laws, eds. Christian MoE, Kari VoGT, Lena LARSEN, Khalid Muhammad MASUD, London: I.B. Tauris, forthcoming (2018).

17 WINTER, Society and Religion, 7.

18 Ibid., 73.

19 Al-QĀḌ̄ 'IYĀḌ, Tartīb al-madārik wa-taqrīb al-masālik li-ma'rifat a'lām madhhab Mālik, eds. Muḥammad IBN Tāwīt al-ṬANJī (vol. I), 'Abd al-Qādir al-ȘAḤRĀWī (vols. II-IV), Muḥammad IBN SHARĪFA (vol. v), and Sa īid Aḥmad A'RĀB (vols. VI-VIII), Rabat: Wizārat al-Awqāf wa'l-Shu'ūn alIslāmiyya, 1983.

20 In the commentary Mashāriq al-anwār 'alà sịhạh al-āthār 'Iyāḍ offered philological comments on the works of Mālik, al-Bukhārī, and Muslim; in the Ikmāl al-mu’lim bi-fawä̉id Muslim (= Sharh Sahīh Muslim) he commented upon Muslim's Șahīḥ; and in his handbook on hadīth transmission, al-Ilmā ilà ma'rifat ușūl al-riwāya wa-taqyīd al-samā', he established a terminological and methodological framework of 'ulüm al-ḩadīth. 
significant scholars and was commented upon by dozens of later scholars from a range of schools and affiliations. ${ }^{21}$

The Mālikī madhhab was second in influence in al-Sha'rān̄̄'s Mamluk Egypt, and there were clearly tensions between Mālikīs, often traditionalistic Maghribis, and scholars affiliated with other madhāhib. ${ }^{22}$ Al-Sha' rānī himself had many Mālikī friends, and he respected them on account of Mālik having been al-Shāfíī’s teacher. ${ }^{23}$ According to Michael Winter, the Mālikī faqīh was, however, perceived by many Egyptian șüfìs as the personified adversary, and al-Sha'rānī bears testimony to the intensity of these memories through retelling incidents where Mālikīs attacked the șūfìs. Al-Ghazālī's book having been attacked, or even burnt, by Mālikī fuqaha $\bar{a}^{\text {' }}$ of Spain was a case in point.

Among al-Sha'rānī's most influential masters was al-Suyūṭī (d. 911/1505), whose works and opinions continued to influence him greatly although he only met him for a short period when he was very young (12 years, a month before al-Suyūṭi died). ${ }^{24}$ Al-Suyūṭi had written a commentary on the Shifä', concentrating on textual critisicm of the ahādìth cited in it. ${ }^{25}$ 'Iyāḍ's work is also likely to have been known to al-Sha'rānī as a source for such great Shāfíī works as al-Nawawī’s (d. 676/1278) al-Minhāj bi-sharh Șaḥīh Muslim, as well as for Taqī al-Dīn al-Subkī's (d. 756/1355) book al-Sayf al-maslūl 'alà man sabba al-rasūl with its many references to 'Iyāḍ's Shifä’', and his son Tāj al-Dīn al-Subkī’s (d. 771/1370) Tabaqāt al-shāfi iyya al-kubrà. In the țabaqāt works on the Shāfíī scholars the controversies surrounding al-Ghazālī's work are a recurrent topic. In his bibliographical entry on al-Ghazālī, al-Subkī includes a chapter where he details the criticisms raised by some of the Mālikīs and the responses to those criticisms. 'Iyāḍ, however, is not mentioned. ${ }^{26}$

On the other hand, the Syrian Shāficī al-Dhahabī (d. 748/1348) reports in his Siyar a lām al-nubalā' from 'Iyāḍ's non-extant Kitāb mu'jam fì shuyūkh Ibn Sukkara ${ }^{27}$ that Abū 'Alī alHusayn al-Șadafī (d. 514/1120), also known as Ibn Sukkara, held the view that al-Ghazāli both exaggerated his mystical leanings (ghalā fì tarīqat al-tașawwuf) and strived to spread his madhhab. ${ }^{28}$ Al-Sadafì was an important traditionist as well as a pious scholar who insisted on keeping his seclusion (ikhtifä'), especially in the later parts of his life. 'Iyād describes in his fahrasa how he prevailed on him to be able to sit with him and read intensively with him during a period in Murcia (beginning of 508/mid-1114). ${ }^{29}$ By

21 See a comprehensive list in Badrī Muḥammad FAHD, "Kitāb al-shifā bi-tacrīf huqūq al-muṣṭafà," alManāhil, 19 (1980): 488-535, 527-534.

22 WINTER, Society and Relgion, 223-225.

23 See biographical entry in al-QĀḌ̄ 'IYĀḌ, Tartīb al-madārik, III: 174-195.

24 WINTER, Society and Religion, 56.

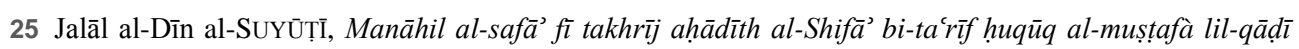
'Iyāẹ, Beirut: Mu’assasat al-Kutub al-Thaqāfiyya; Dār al-Jinān, 1988.

26 Tāj al-Dīn 'Abd al-Wahhāb al-SuBKĪ, Ṭabaqāt al-shāfi iyya al-kubrà, ed. Mușțafâ 'Abd al-Qādir 'AṬ̂̄, 6 vols., Beirut: Dār al-Kutub al-'Ilmiyya, 1999, III: 443-456.

27 Al-QĀḌ̄ 'IYĀḌ, al-Ghunya, 130.

28 Muḥammad Ibn Aḥmad al-DHAHABĪ, Siyar a 'ām al-nubalā’, ed. Shu'ayb al-ARNĀ'ŪṬ, 23 vols., Beirut: Mu’assasat al-Risāla, 1985, XIX: 329, cf. GHRĀB, "Ḥawla iḥrāq al-murābiṭin li-Ihyyā’ al-Ghazālī," 153.

29 Al-QĀḌ̄ 'IYĀḌ, al-Ghunya, 129-136; also Ibn Hamāda, Mukhtaṣar, printed in al-QĀḌ̄ 'IYĀḌ, Tartīb almadārik, VIII: 193-194.

زحis • 18 (2018): 87-109 


\section{A book burner or not? Revisiting al-Qāḍī 'lyāọ}

spreading al-Ghazālı̄’s teachings an unwanted uncertainty was incited, al-Dhahabī’s citation continues, and "here in the Far West ('indana fi 'l-Maghrib) the ruler implemented an order and the scholars a fatwà to burn it and to take distance from it. ${ }^{, 30}$ There is some confusion as to who the original source of the wording is, but as neither al-Șadafì nor al-Dhahabī lived in the Maghrib, it may be reasonable to attribute the statement to 'Iyād. However, in the statement 'Iyād did not identify the ruler or scholars in question. Moreover, he neither endorsed nor opposed the action. It appears simply as a descriptive statement, which confirms that the order to burn the book was issued but which does not clarify 'Iyāḍ's potential role in the incident. Nevertheless, it does present us with a possible source for his name being included in the later sources' retelling of the story.

\section{Refutations of al-Ghazālī in the Islamic West}

A number of refutations of al-Ghazālī's teachings are reported to have appeared in alMaghrib and al-Andalus, and 'Iyād reports in his fahrasa that he had read one of them, written by Ibn Hamdīn (d. 508/1114) ${ }^{31}$ However no text of a refutation (radd) has come down to us, nor has documentation of a formal fatwà on burning the Ihy $\bar{a}^{, 32},{ }^{32}$ neither from 'Iyāụ nor from the faqīh and later qā Codoba, exchanged legal arguments with and considered among his masters. ${ }^{33}$ When 'Iyāọ died, he had left behind many notes including fatwàs, which his son, Muhammad Ibn 'Iyāọ (d. 575/1179-80), collected in the work Madhāhib al-hukkām fi nawāzil al-ahkām. ${ }^{34}$ Most fatwàs are from other scholars, as 'Iyād acted more often as the mustaftì than as a muftī. ${ }^{35}$ He communicated extensively on legal issues, and often in written form, with scholars in the region, although legal consultations at the local legal counsel may have taken place without any written documentation. By the time Ibn 'Iyāḍ wrote the Madhāhib al-hukkām, the Almohads had replaced the Almoravids, and it is possible that Ibn 'Iyād left out such

30 Al-DHAHABĪ, Siyar a 'lām al-nubalä’, XIX: 329.

31 Al-QĀD̄ī 'IYĀḌ, al-Ghunya, 46.

32 SERRANO, "Why Did the Scholars of al-Andalus Distrust al-Ghazālī?" 137-138. An exception to this is a text written against al-Ghazālī by Muḥammad Ibn Khalaf al-Awsī (d. 537/1142) (Dominique URVOY, "Le Manuscrit Ar. 1483 de l'Escurial et la Polemique contre Gazālī dans al-Andalus," Arabica, 40.1 (1993): 114-119), but there is no known link between him and 'Iyāḍ.

33 Al-QĀḌ̄ 'IYĀḌ, al-Ghunya, 54-57.

34 Muḥammad IBN 'IYĀḌ, Madhāhib al-ḥukkām fì nawāzil al-aḥkām, ed. Muhammad Ibn Sharīfa, Beirut: Dār al-gharb al-islāmī, (1990) 1997, translated into Spanish in Muhammad IBN 'IYĀḌ, Madhāhib alhukkām fì nawāzil al-aḥkām = La actuación de los jueces en los procesos judiciales (Fuentes arábicohispanas 22), [transl.] Delfina SERRANO, Madrid: Agencia Española de Cooperación Internacional, 1998. See Delfina SERRANO, "Legal Practice in an Andalusī-Maghribī Source from the Twelfth Century CE: The Madhāhib al-ḥukkām fī nawāzil al-aḥkām," Islamic Law and Society, 7.2 (2000): 187-234.

35 Al-Wansharīsī (d. 914/1508) reports only a handful of fatāwī from 'Iyāḍ, given either in Ceuta or Granada during his service as a judge there in 531-532/1136-1137. None of these fatāwi are relevant to the banning or burning of al-Ghazālī's work (Aḥmad Ibn Yaḥyà al-WANSHARĪsĪ, Mi'yār al-mu'rib wa'ljāmic al-mughrib 'an fatāwà ahl Ifrīqiyā wa'l-Andalus wa'l-Maghrib, ed. Muhammad Hajj̄ì, 13 vols., Fez: Wizārat al-Awqāf wa'l-Shu’ūn al-Islāmiyya lil-Mamlaka al-Maghribiyya, 1981). 
fatwàs which in one way or another may have appeared incriminating to his father's legacy. However, such speculations cannot compensate for the lack of historical evidence.

'Iyâd was no opponent to the pious practices of the mystics, and in his biographical dictionaries he often commended pious relinquishment of worldly life (al-zuhd fi ' $l$-dunyā). However, zuhd was not considered a formal, bookish discipline, ${ }^{36}$ and the conflict was not one of pious practices but one of epistemological tools and interpretational privilege. The

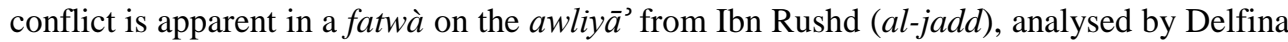
Serrano, who holds that the issue pertained to the pertinent questions of the relationship between knowledge and authority. ${ }^{37}$ But this fatwà also testifies to the fact that Ibn Rushd was among the scholars who engaged vigorously with al-Ghazālī’s work. The problem which was laid before Ibn Rushd was the implications for the traditional scholars in alGhazālī's epistemological hierarchy, where the "friends of God" (al-awliy $\bar{a}$ ) and people of mystic insights (al-'ārifün) ranked above scholars of theology and law (al-'ulamä' bi'lahkām). Ibn Rushd explained the problem in terms of two categories: people who know God (al-'ārifūn bi-'llāh) and people who know God's norms (al-'ārifūn bi-aḥkām Allāh). Serrano concludes that Ibn Rushd in this question took a conciliatory position, holding that although on a general basis the mystics are ranked higher when it comes to closeness to God, in their absence, the scholars of theology and law, i.e., scholars like himself, and by extension, one could hold, like 'Iyāḍ, are the best available interpreters of God's commands. $^{38}$

The concept of awliy $\bar{a}$ ' occurs several times in 'Iyāḍ's biographical dictionary Tartīb almadārik as a descriptive term, probably used in a generic sense of saintly mystics. However, in his introduction to the Tartīb al-madārik, 'Iyāḍ establishes an epistemological genealogy: God sent prophets to guide human beings towards knowledge, truth and justice ('ilm, sidq and ' $a d l$ ), and Muhammad ranks as the last of these prophets, while people of knowledge ('ulama $\bar{a}^{\prime}$ ), with the a'immat al-muslimin at the forefront, are continuing this work down the centuries. ${ }^{39}$ Thus, in the same way as his teacher and colleague Ibn Rushd, 'Iyâd allots interpretational priority to the scholars of theology and law (al-'ulama $\bar{a}^{\text {' }}$ bi'l$a h k \bar{a} m$ ) rather than to the people of mystic insights (al-' $\bar{a} r i f \bar{u} n)$.

\section{Al-Zabīdī’s story of Ibn Ḥirzihim}

In the eighteenth-century al-Zabīdī's retelling of al-Sha'rānī's anecdote, he modifies alSha'rān̄̄'s account slightly, first by removing Ibn Rushd's name, then by ascertaining, without further comment, the historically known date of 'Iyāḍ's death. However, al-Zabīdī also refers to the story of Ibn Hirzihim (d. 559/1164) from Fez, a near-contemporary to

36 Juan M. Vizcaíno identified the limited number of five works on $z u h d$, out of a total of around 250 works 'Iyāḍ mentions that he studied (Juan M. VIzCAínO, "Las obras de zuhd en al-Andalus," alQantara, 12.2 (1991): 417-438).

37 SERRANO, "Why Did the Scholars of al-Andalus Distrust al-Ghazālī?" See also FIERRO, "Opposition to Sufism,” 193-197 for the conflicts over al-Ghazālī’s șūfi inclinations.

38 SERRANO, "Why Did the Scholars of al-Andalus Distrust al-Ghazālī?" 154.

39 Al-QĀḌ̄ 'IYĀḌ, Tartīb al-madārik, I: 1-5.

jais • 18 (2018): 87-109 
'Iyāẹ. ${ }^{40}$ cAlī Ibn Hirzihim had taken Ghazālian knowledge from his uncle Abū Muhammad Ibn Șāliḥ Ibn Hirzihim (d. 505/1112), who had taken it from al-Ghazālī himself when he had travelled to the East, and also from Abū 'l-Faḍl Ibn al-Nahwīi (d. 513/1119 or 20). 'Alī Ibn Hirzihim is reported to have dreamt that he had kept a copy of the Ihya', in spite of an explicit ban. He showed the book to some of his friends, who said that "the previously mentioned shaykh" attacked al-Ghazāli and forbade the reading of his books, and then he, Ibn Hirzihim, had to take a beating. In a dream Ibn Hirzihim saw al-Ghazālī, who complained about him to the Prophet. Ibn Hirzihim told the Prophet that al-Ghazāin had suggested that he, Ibn Hirzihim, had falsely attributed some statements to the Prophet, whereupon the Prophet ordered Ibn Hirzihim to be beaten. ${ }^{41}$ After this incident, Ibn

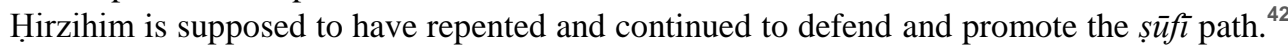
The words "the previously mentioned shaykh" probably refer to al-Zabīdī's previous mention of 'Iyāḍ, and consequently it is al-Zabīdī who here suggests a link to 'Iyāọ for condemning the Ihy $\bar{a}$ '. However, in the much earlier source for Ibn Hirzihim's story, Yūsuf Ibn Yahyà Ibn al-Zayyāt al-Tādilī’s (d. 617/1231) al-Tashawwuf ilà rijāl al-taṣawwuf, such a link is neither stated nor suggested. Here, 'Iyāẹ is not mentioned at all. ${ }^{43}$ Al-Tādilī also tells the story somewhat differently:

I secluded myself in a house to read al-Ghazālī's Ihyya' 'ulūm al-dīn for a portion of a year. When I reached the issues he was criticized for, I pledged to burn the book. But when I slept I saw someone order me to be beaten as a punishment for lying. So I was beaten eighty stripes, and when I woke up I found myself in great pain from the beating. ${ }^{44}$

According to al-Tādilī̄, Ibn Hirzihim then repented, pondered over the issues again, and this time he found them not to contradict the Qur'ān and the Sunna.

\section{Ibn al-'Imād's reference to the burning of the Ihyā'}

The second oft-cited secondary reference to 'Iyâḍ's alleged role in the condemning and burning of al-Ghazālī's Ihyā', provided by Delfina Serrano Ruano, is Ibn al-'Imād (d. 1089/ 1679). ${ }^{45}$ This Syrian Hanbalī scholar wrote a comprehensive, annalistically arranged biographical history. ${ }^{46}$ Most scholarly entries are organized according to year of death, and

40 Al-ZABĪDĪ, Ithāff, I: 27-28.

41 A similar story is told elsewhere about "a man from Egypt." See MACDONALD, "The Life of al-Ghazzālī," 109.

42 For instance, contrary to the amīr 'Alī b. Yūsuf's order, he saw to it that people gave the suuf $\bar{\imath}$ Ibn Barrajān a worthy funeral in 536/1141 (CASEWIT, The Mystics of al-Andalus, 125).

43 Yūsuf Ibn Yahyà Ibn al-Zayyāt al-TĀDILĪ, al-Tashawwuf ilà rijāl al-tașawwuf wa-akhbār Abì 'l-'Abbās al-Sabtī, ed. Aḥmad TAWFīQ, Rabat: Kulliyyat al-Ādāb wa'l-'Ulūm al-Insāniyya, 1984: 168-173.

44 Ibid., 169.

45 Serrano, "Why Did the Scholars of al-Andalus Distrust al-Ghazālī?" 138, footnote 10; SERrano, "Los Banū 'Iyāẹ."

46 'Abd al-Ḥayy Ibn Aḥmad IBN al-'IMĀD, Shadharāt al-dhahab fí akhbār man dhahab, ed. 'Abd al-Qādir 
in the entry on 544 (=1149), we find 'Iyāḍ presented in a few paragraphs. Ibn al-'Imād praises 'Iyạ̄ highly, describing him as among the best men of his age and a staunch defender of the Sunna, to a degree that "he ordered al-Ghazālī's books to be burnt because of the delusions he gained from them (li-amri tawahhumihi minhā)" ${ }^{47}$ The statement does suggest that 'Iyāḍ had been reading al-Ghazālī's work and had found them alluring but eventually had come to realize that their appeal was delusional more than instructive, but Ibn al-'Imād does not refer to any sources for his allegation. ${ }^{48}$

In the entry Ibn al-'Imād also alludes to the tense personal situation 'Iyāḍ found himself in, possibly a reference to the turmoil he experienced in the transitional phase between the Almoravid and the Almohad governments. Ibn al-'Imād quotes a poem also found in Ibn Khallikān's (d. 681/1282) biographical dictionary, where he writes that a certain (unidentified) legal scholar Abū 'l-Ḥasan Ibn Hārūn from Malaga wrote a poem acknowledging the unfair treatment 'Iyāọ had received: "They wronged 'Iyāọ, while he showed forbearance to them, but wrongdoing in this world is ancient [...]". ${ }^{49}$ The fourteenth-century historian Ibn al-Khațīb (d. 776/1374) is even more outspoken when describing 'Iyāḍ's final journey to Marrākash as one of overpowering (taghallub), uprooting (isti’̣āal) and expelling (musharradan bihi) ${ }^{50}$ However, neither of these last two, or any of the other available early biographical sources_-Ibn Khāqān (d. 529/1134), Ibn Bashkuwāl (d. 578/1183), Ibn alAbbār (d. 658/1260), Ibn Khallikān (d. 681/1282), Ibn al-Khațīb (d. 776/1374), Ibn Farḥūn (d. 799/139) ${ }^{51}$ — conveys any information on 'Iyāḍ's possible role in the controversies surrounding al-Ghazālī’s writings. Shihāb al-Dīn al-Maqqarī al-Tilmisān̄̄ (d. 1041/1632), who wrote a comprehensive work on 'Iyāẹ and included the history of scholarly, political, and social life in the West in a broader sense, and who refers to some of the scholarly

al-ARNĀ'ŪṬ and Mạ̣mūd al-ARNĀ'ŪṬ, 10 vols., Damascus \& Beirut: Dār Ibn Kathīr, 1986-1993.

47 Ibid., VI: 226-227.

48 Al-Sha'rānī is not mentioned among the few general sources listed. Ibn Khallikān is mentioned, but although he provides biographies for many of the relevant individuals, he does not mention that 'Iyād had any hand in the banning or burning of the Ihyā' (IBN al-'IMĀD, Shadharāt al-dhahab, I: 111-112).

49 IBN KHALLIKĀN, Wafayāt al-a yān wa-anbā' abnā’ al-zamān, ed. Yūsuf 'Alī ṬAWĪL and Maryam Qāsim ȚAWĪL, Beirut: Dār al-kutub al-'ilmiyya, 6 vols., iii: 424-426. The poem in not included in Mac Guckin de Slane's translation (IBN KHALLIKĀN, Wafayāt al-a'yān wa-anbā' abnä' az-zamān (Deaths of Eminent Men and History of the Sons of the Epoch), transl. MAC GUCKIN DE SLANE, 4 vols., Beirut: Librarie du Liban, 1970, ii: 417-419).

50 IBN al-KHAṬīB, al-Iḥāṭa fì akhbār Gharnāṭa, ed. Būziyyānī al-DARĀJĪ, Algiers: Dār al-Amal li'l-dirāsāt, 2009, v: 152-153.

51 IBN KHĀQĀN, Qalāìd al- 'iqyān wa-mahāsin al-a ‘yān, ed. Husayn Yūsuf KHARYūsH, Zarqā’ (Jordan): Maktabat al-Manār, 1989, ii: 683-691; IBN BASHKUWĀL, Kitāb al-șila, ed. Ibrāhīm al-ABYĀRĪ, 3 vols., Cairo: Dār al-Kitāb al-Mișrī / Beirut: Dār al-Kitāb al-Lubnān̄̄, 1989, ii: 94; IBN al-ABBĀR, al-Mưjam fì

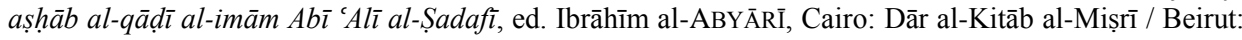
Dār al-Kitāb al-Lubnān̄̄, 1989: 294-298; IBN KHALLIKĀN, Wafayāt, iii: 424-426, transl. DE SLANE, ii: 417-419; IBN al-KHAṬīB, al-Ihạța, v: 152-153; IBN FARḤŪN, al-Dībāj al-mudhahab fì ma'rifat a'yān 'ulamā' al-madhhab, ed. Muḥammad al-Aḥmadī ABŪ 'L-NŪR, 2 vols., Cairo: Dār al-Turāth, 1972, ii: 46-51.

jais • 18 (2018): 87-109 
discords of the period, mentions al-Ghazālī only a few times, all of which are in connection to him having been the teacher of 'Abū Bakr Ibn al-'Arabī (d. 543/1148). ${ }^{52}$

\section{The burning incidents in Almohad historiology}

Some early sources from the Islamic West mention the burning incidents and the involvement of various people in different ways. Yūsuf Ibn Țumlūs (d. 620/1223) in his book on logic considered, among other topics, the teachings of al-Ghazālī. He said that when al-Ghazālī's work reached al-Andalus, scholars found them to contain things they had never heard about before, about al-șüfiyya and other issues. ${ }^{53}$ Their reaction was, according to Ibn Tumlūs, that: "if there is such a thing as kufr and zandaqa in this world, it surely is to be found in al-Ghazālī's books." Therefore they urged the amīr to burn the books which in their view could lead to misguidance ( $(a) \bar{a} l)$. And the books were burnt before anyone really knew what was in them, and everyone throughout the empire (mamlaka) was ordered to burn them and punish the people who kept them. What pushed the amir to this was the point of view of the scholars, Ibn Tumlūs wrote. According to him the decrees were read from the minbar, and the most famous scholar to suffer from this trial was Abū Bakr Ibn al'Arabī. But then came al-imām al-mahd̄̄, Ibn Țumlūs continued, and the confusions (tahayyur) of the people were corrected and he set them free to read al-Ghazālī's books. ${ }^{54}$

According to the Almohad chronicler 'Abd al-Wāhid al-Marrākushī (d. 647/1250) it was 'Alī Ibn Yūsuf (r. 500-537/1106-1143) who ordered the Ihya $\vec{a}$ to be burnt in 509/1115. ${ }^{55}$ However, al-Marrākushī remarks that the Almoravids under 'Alī Ibn Yūsuf's reign gave the scholars a large role, too large for his own liking. The ruler would not make any political decision without asking the fuqah $\bar{a}^{\text {, }}$, and so would people in general, whether it was on small or big issues. This gave the fuqah $\bar{a}^{3}$ too much authority and it enabled them to amass wealth, al-Marrākushī complains. He cites some satirical verses accusing the scholars in general, and Abū 'Abd Allāh Ibn Ḥamdīn (d. 508/1114) in particular, for abusing Mālik's tradition for worldly gain. Al-Marrākushī criticized them for keeping exclusively to their own Mālikī canon to a point where they "forgot to consider God's book and the Hadīth of the Prophet." A final point of criticism was that they would excommunicate (takfir) anyone who in any way engaged in scholastic theology ( ${ }^{i} \mathrm{llm}$ al-kalām). As a consequence of this,

52 Shihāb al-Dīn Aḥmad Ibn Muhammad al-Maqqarī al-TiLmisĀNī, Azhār al-Riyāẹ fì akhbār al-Qāộ̄ 'Iyāẹ, ed. Muṣtafà al-SAQQÀ, Ibrāhīm al-ABYĀRĪ and 'Abd al-Hafīz SHIBLĪ, 5 vols., Cairo: Maṭbū'āt Lajnat al-Ta'līf wa'l-Tarjama wa'l-Nashr, [1939-1942]), III: 62-62, 91; IV: 247; V: 57.

53 Yūsuf IBN ȚUMLUS, al-Madkhal li-șinā'at al-manțiq, ed. Mīkā̄̄il AsīN, Madrid: al-Maktaba al-Abīriqa, 1916: 11-12.

54 Abū Bakr Ibn al-'Arabī was not the only one to suffer from the prohibition, and other scholars protested it, most famously 'Alī al-Juhdāmī al-Barjī (d. 509/1115), who was removed from the shūrà for opposing the official order (see SAFRAN, "The politics of book burning," 160). However, Ibn al-'Arabī is the only name among these opponents that I have been able to establish as having an immediate connection to 'Iyāẹ.

55 'Abd al-Wāḥid al-MARRĀKUSHĪ, al-Mu'jam fì talkhị̄ akhbār al-Maghrib, ed. Khalīl 'Imrān al-MANȘŪR, Beirut: Dār al-kutub al-'Ilmiyya, 1998: 121-122, transl. in E. FAGNAN, Histoire de l'Afrique et de l'Espagne intitulée al-Bayano l-Mogrib, Algiers: Imprimerie Oriental P. Fontana, 1901-04: 147-149. 
when al-Ghazālī's books were introduced to the West (al-Maghrib), the amīr al-musliminn, 'Alī Ibn Yūsuf, banned them and ordered them to be burned. It is here suggested that it was Ibn Hamdīn, chief judge in Cordoba at the time (505-508/1111-1114) ${ }^{56}$ who was the main instigator of the first controversy.

Another Almohad chronicler, Ibn al-Qatțān (mid-seventh/mid-thirteenth century), was more decisive in his confirmation that 'Alī Ibn Yūsuf ordered the burning of the Ihy $\bar{a}$ ' in $503 / 1109$ on the authority of ('an) a consensus among chief judge Ibn Hamdīn and Cordoba's jurists. ${ }^{57}$ Ibn al-Qattān also confirmed that the burning actually took place at the Western gate of the grand mosque with many notables present. Books were torn from the hands of people, among them Ibn al-'Arabī. Ibn Hamdīn had been 'Iyāḍ's mentor during his seven-month stay in Cordoba in 507/1113-1114, and 'Iyāḍ reports that he had read Ibn Hamdīn's polemic essay refuting al-Ghazālī (Risālat al-radd 'alà 'l-Ghazālì, non-extant) while he was there. ${ }^{58}$ The Hamdīns came from an influential family, and Abū 'Abd Allāh Ibn Hamdīn had a powerful position and, contrary to some perceptions of his weak scholarship, 'Iyād praised his knowledge and scholarly standing. ${ }^{59}$

Ibn al-Qattān interprets the burning in a political context, calls it an act of people of ignorance (jahala) that was meant to secure their government (mulk), and says that it was only reversed when the amīr al-'azizz al-qä̉im bi'l-haqq (Ibn Tūmart) made it available again. In this connection Ibn al-Qațtān tells the reader about Ibn Tūmart's travels East and his meeting with al-Ghazālī. At this meeting in 508/1114, according to Ibn al-Qațtān, alGhazālī heard about the reception of his work and prayed for their empire to be torn as his work had been torn. Ibn Tūmart asked him to pray that he should be the instrument for this, al-Ghazālī so did and the prayer was answered, says Ibn al-Qațān. ${ }^{60}$ Obviously, as far as the historicity of the narrative goes, this is a misreading on Ibn al-Qatțān's part, as alGhazālī was already dead in 505/1111.

56 Vincent LAGARDÈRE, "La hauète judicature à l'époque almoravide en al-Andalus," al-Qanțara, 7.1 (1986): 135-228, 142.

57 Abū Muhammad Ḥasan Ibn 'Alī IBN AL-QAȚṬĀN al-Marrākushī, Nužum al-jumān li-tartīb mā salafa min akhbār al-zamān, ed. Maḥmūd 'Alī MAKKī, Beirut: Dār al-gharb al-islāmī, 1990: 70-72. Maribel Fierro notices that Muhỵī 'l-Dīn Ibn 'Arabī identified his son Abū 'l-Qāsim Ibn Hamdīn (judge of Cordoba 508-511/1114-1118 and 513-521/1119-1127) as the one responsible for the burning (FIERRO, "Opposition to Sufism," 186, footnote 40). Muhyyī 'l-Dīn tells a story where a certain Abū 'Abd Allāh Ibn Zayn al-Yābirī in Sevilla one night was reading book of a Abū 'l-Qāsim Ibn Aḥmad (not identified as Ibn Hamdīn here) criticising Abū Hamid (al-Ghazālī), whereupon Abū 'Abd Allāh was blinded. When he promised never to read the book again, his sight returned to him (IBN al-'ARABI, Risālat rū al-qudus fì muhāsabat al-nafs wa'l-mabādi' wa'l-ghāyāt fí-mā tatadammanuhu hurūf al-mu'jam min al'ajä’ib wa'l-āyāt, ed. 'Izzat ḤușRIYYA, Damascus: Mațba'at al-'Ilm, 1970: 123).

58 Al-QĀDī 'IYĀḌ, al-Ghunya, 46.

59 Ibid.; al-QĀḌ̄ 'IYĀḌ, Tartīb al-madārik, viii: 193.

60 IBN al-QATṬ̂̄N, Nuzum al-jumān, 73. This incident is also reported by al-Marrākushī with the variation that Ibn Tūmart was present at the meeting, and al-Ghazālī said that someone present at the meeting would be the most suitable for the task but that he did not address Ibn Tümart directly (alMARRĀKUSHĪ, al-Mu'jam, 127, transl. FAGNAN, Histoire de l'Afrique, 155). The official historian of the Marinid dynasty, which followed the Almohads, Ibn al-Ahmar (d. 807/1405), told the story with the variant that the tearing apart of the empire took place at the hands of the Christians (Ismā $\overline{1}$ Il IBN alAḤMAR, Buyūtāt Fās al-kubrà, Rabat: Dār al-Manșūr lil-țibā'a wa'l-warāqa, 1972: 34-35).

\footnotetext{
jais • 18 (2018): 87-109
} 
According to the sources, scholars were of different opinions in the matter and the ban was countered by several judicial statements. Janina M. Safran suggests that scholarly disagreement as well as his own professional rivalry was a main impetus for Ibn Hamdīn's reactions towards al-Ghazālī's work. ${ }^{61}$ Ibn al- 'Arabī (d. 543/1148) had returned from the East in 495/1102, when Yūsuf Ibn Tāshfīn was still ruling (r. 453-500/1061-1106), with the official investiture of the Almoravid government from the 'Abbāsid caliph. He had been appointed chief judge in Seville (528/1134-538/1143), ${ }^{62}$ a city which was competing with Cordoba for the supreme status in al-Andalus. There was also professional rivalry between Ibn Hamdīn and the younger and quite dynamic Ibn Rushd (al-jadd). Ibn Hamdīn may have seen the controversies as a way to demonstrate his own position and his unique ties to the ruler. On the other hand, 'Alī Ibn Yūsuf, ruler from 500/1106, may have seized the opportunity to bolster his political legitimacy by the same ties. Thus, as Safran suggests, the first controversy may be understood as "a symbolic enactment of the negotiation of authority between ruler and jurists." ${ }^{, 63}$ However, as Serrano holds, "any direct relationship between the criticisms formulated by the jurists and the royal decree is not to be taken for granted." ${ }^{, 64}$

The second burning incident was instigated by the new ruler, Tāshfīn Ibn 'Alī (r. 537539/1143-1145), when he had just risen to power following his father's long reign. The order is documented in a letter dated the first third of Jumādà I 538 (= mid-November 1143) and addresses the scholars, officials, and the people of Valencia. ${ }^{65}$ In the letter, Tāshfin appeals to the religious convictions and feelings of his addressees, although the formula is quite standard for an official letter of admonition, inducing fear of God. The closest to God is the one who loves his servants, and the best in our eyes are clerks and judges who consult the best sources and speak well, Tāshfīn writes. ${ }^{66} \mathrm{He}$ reminds his addressees of the obligations of prayer, righteousness and jihād, then impresses upon “every judge and muft $\vec{\imath}$ ' to follow the Mālikī madhhab, and

if you ever come across a book of innovation (bid'a) or someone preaching innovations, and especially_may God help you - the books of Abū Hāmid alGhazāīi, then follow their trails and stop their influence by burning them as their concealed [message] (kitmān) constitutes a threat to the faith (īmān). ${ }^{67}$

In contrast to what was reported about his father's order being supported by the scholars of Cordoba, Tāshfīn neither explicitly nor implicitly evokes scholarly authority in the

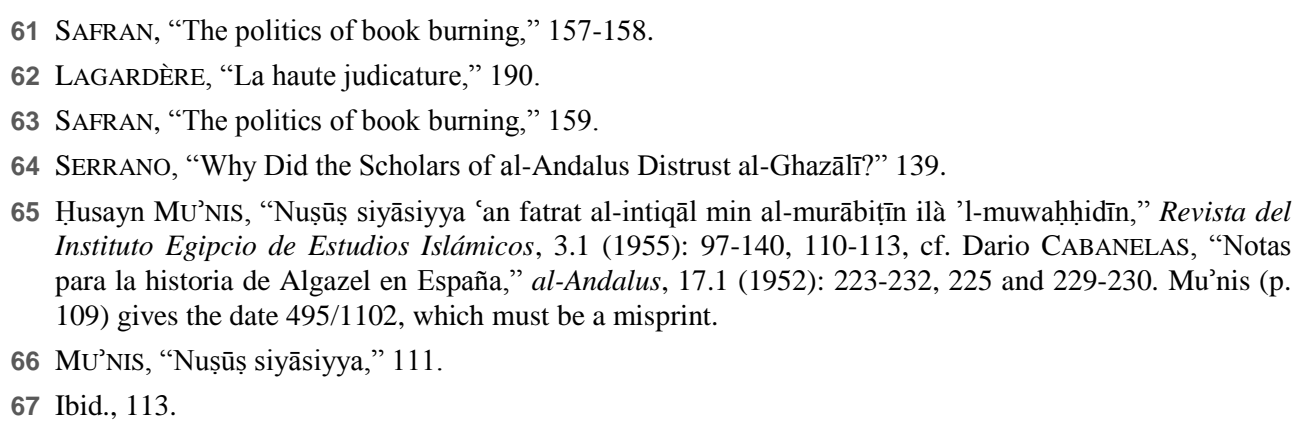


Nora S. Eggen

Valencia letter; rather he appeals to scholars on the grounds of his own executional authority. The ban may have been a reaction against the growing support for the Almohads in the Maghrib and al-Andalus, in an attempt to tie scholars, notables and the general public closer to the Almoravid central power. However, and again contrary to the first incident, the sources do not tell us that the burning actually took place. Neither the first nor the second ban stopped the Andalusian scholars from engaging with al-Ghazālī's work. ${ }^{68}$ But whereas the first ban was protested by some scholars, the second ban received less attention. The reason for this may be that it was less known or more locally oriented or, as Yousef Casewit remarks, by the 530s/1140s "a new generation of mystics had [...] merged Andalusi mystical teachings with their understanding of the Ihy $\bar{a}$," and the politicization of the Ghazālian issue was of a different kind with the Almohads as the rising power. ${ }^{69}$

\section{Engagement with al-Ghazālī among 'lyāọl's contacts}

According to his biographer-son, Muhammad Ibn 'Iyāḍ, 'Iyāḍ's view of the Ihyā' was favourable. ${ }^{70}$ On the authority of his paternal cousin Abu 'Abd Allāh, who worked as a secretary for 'Iyāḍ, Ibn 'Iyāḍ tells us about a conversation between 'Iyāḍ and his teacher in

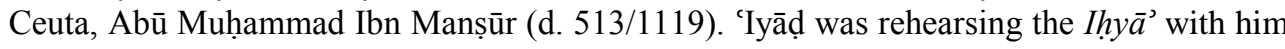
and remarked that an abridged version bringing out the pure knowledge in it ( $m \bar{a} f i-h i$ min khāliṣ al- ${ }^{\mathrm{i}} \mathrm{lm}$ ) would be most useful. Ibn Manșūr replied that 'Iyāẹ himself would be the most suitable person to write such a book: "If you do not abridge it, nobody in our land will." As far as is known, no such book ever appeared, although some of the ideas from the Ihy $\bar{a} \vec{a}^{\prime}$ may have been included in some of 'Iyāḍ's own work. ${ }^{71}$ In his fahrasa, 'Iyāḍ praises Ibn Manșūr highly and says he benefitted from his knowledge. ${ }^{72}$ The rehearsing would have taken place in one of the two periods Ibn Manșūr spent in Ceuta, first a period sometime after year 500/1106-7 and second from beginning 512/mid-1118 until he died in Sha'bān 513/November 1119. However, 'Iyād does not mention having read the Ihy $\bar{a}^{\prime}$ with him.

In his fahrasa, 'Iyād does not mention that he read the Ihy $\bar{a}$, nor any other of alGhazālī's works. However, he does mention that he had contact with a few Shāfi'īs, and that he met a number of people who most probably had read it. He had written communication with Abū 'l-Qāsim al-'Akāfī (d. 549/1154) who wrote to 'Iyāẹ from Mecca authorizing him for all his transmissions and who, according to 'Iyāḍ, had among others taken knowledge from al-Ghazālī in Nishapur. ${ }^{73} \mathrm{He}$ also met in person with a tradesman, Sahl al-Nīsābūrī (d. 531/1136), with whom he sat while he stopped in Ceuta. 'Iyâḍ writes that Sahl al-Nīsābūrī had told him that he had met and sat with al-Juwaynī as well as his

68 GARDEN, The First Islamic Reviver, 166.

69 CASEWIT, The Mystics of al-Andalus, 53.

70 IBN 'IYĀḌ, al-Ta'rīf, 106-107.

71 A. J. Wensinck, The Muslim Creed: Its Genesis and Historic Development, Cambridge: Cambridge University Press, 1932: 272-275. See more below.

72 Al-QĀDī 'IYĀḌ, al-Ghunya, 155-156.

73 Ibid., 166.

زحis • 18 (2018): 87-109 
friends al-Qushayrī and al-Ṭūsī [al-Ghazālī] in Nishapur. ${ }^{74}$ Unfortunately, no dates are given for any of these encounters, and there is no trace of any transmissions from alGhazāli through any of these two contacts.

In the long list of 'Iyāḍ's accomplishments and personal characteristics, Ibn 'Iyāḍ writes that he, being a scholar of fiqh and all the different disciplines of hadith, had been a legal theoretician (ușüliyyan) as well as a theologian (mutakalliman), and that he had taken an interest in șüfi men and their thoughts as well. ${ }^{75}$ As Ibn 'Iyāọ was writing during the early Almohad days, Delfina Serrano Ruano interprets these statements as apologetic, in view of Almoravid scholars having been accused of prioritizing fur $\bar{u}^{c}$ over $u s ̣ \bar{u} l$ and neglecting kalamm. ${ }^{76}$ It is within this framework that Serrano seeks to understand the first anecdote on the Ihy $y \bar{a}^{\text {' }}$ as well, arguing that with this anecdote, Ibn 'Iyād is trying to counterbalance his father's unfavourable role in the condemnation and burning. However, Ibn 'Iyād does not mention the burning, and the only other source Serrano presents for 'Iyāḍ's having a role in the incident is al-Sha' rānī. ${ }^{77}$

One of the complaints among the Mālikīs about al-Ghazālī was that he allegedly had slandered both Mālik and the great Mālikī-Ash'arī scholar Abū Bakr al-Bāqillānī (d. 403/1013). In the Tartīb al-madārik, 'Iyāḍ counts al-Ghazālī among the scholars who had conveyed misconceptions about Mālik's view of $i j m \bar{a}^{c}$ ahl al-Madinna ${ }^{78}$ saying that some of them went as far as almost defaming Medina itself because they distorted what the Mālikīs actually said regarding their distinction between a Medinan $i j m \bar{a}^{c}$ which was transmitted $k \bar{a} f f a$ 'an kâffa, amounting to decisive legal argument (hujja), and a Medinan ijmā $\bar{a}^{`}$ based on al-ijtihād wa'l-istidlāl, which was not considered hujja. According to 'Iyāḍ, al-Ghazālī wrongly assumed that these forms of Medinan $i j m \bar{a}^{c}$ were the only valid $i j m \bar{a}^{c}$ for the Mālikīs, which, he states, was a complete misconception. What Iyāọ does is simply to criticize non-Mālikī scholars, and al-Ghazālī among them, for not having taken matters into proper consideration before passing judgement. ${ }^{79}$ However, 'Iyāẹ does not refer to any sources for these allegations, and we do not know whether they stem from 'Iyâḍ's own reading of al-Ghazālı̄'s work or from some of his contemporaries who discussed alGhazālī's teachings.

In Jerusalem in 489 or $490 / 1096$ or 1097, al-Ghazālī composed his al-Risāla alQudsiyya, which was included in the Ihyā' (Book 2, Kitāb qawāं id al- $\left.{ }^{\top} a q \bar{a}^{\top} i d\right) .{ }^{80}$ A.J. Wensinck suggested that 'Iyạ̣̄ in his theological treatise al-I'lām bi-ḥudūd qawā'id al$i s l \bar{a} m^{81}$ was very influenced by this risāla, particularly in the fourty propositions on the

\footnotetext{
74 Ibid., 209.

75 IBN 'IYĀḌ, al-Ta'rîf, 4-5.

76 SERRANO, "Los Banū 'Iyāẹ," 362-364.

77 Ibid., 364, footnote 54.

78 Al-QĀḌ̂̄ 'IYĀḌ, Tartīb al-madārik, I: 47.

79 Ibid., I: 53. See also Umar F. Abd-Allah WyMAnN-LANDGRAF, Mālik and Medina: Islamic Legal Reasoning in the Formative Period, Leiden: Brill, 2013: 15.

80 HourANI, “A Revised Chronology of Ghazālī’s Writings,” 289-302, 295-296.

81 Al-QĀḌ̄ 'IYĀḌ, al-I lām bi-ḥudūd qawāi id al-islām, eds. Muhammad Șadīq al-MINSHĀWĪ and Muhammad 'Abd al-Raḥmān 'ABD AL-MuN'IM, Cairo: Dār al-Faḍīla, 1995.
} 
shahādatayn. ${ }^{82}$ I have not found any textual evidence that 'Iyāḍ read the risāla as a separate text, but he may have read it as part of the Ihy $\bar{a}$. One of 'Iyāḍ's contemporaries and close contacts who met al-Ghazālī was the Sevillan Mālikī scholar Ibn al-'Arabī (d. 543/1148). During his journey east along with his father, Ibn al-'Arabī met many of the great scholars. The then less than twenty-year old Ibn al-'Arabī became for a period of time one of alGhazālī's closest students, and he read the newly composed, or possibly not yet completed, Ihy $\vec{a}^{\text {' }}$ in Baghdad in 490/1097. ${ }^{83}$ Subsequently, he introduced the Ihy $\vec{a}^{\prime}$ into the West when he returned to Sevilla in 495/1102, and he may have conveyed some of its content or given the young student 'Iyā the chance to copy some notes in Ceuta when possibly stopping there on his way from Fez to Seville. ${ }^{84}$ Born in 468/1076, Ibn al-'Arabī was 'Iyāḍ’s (b. 476/1083) senior by only a few years. Later 'Iyāẹ met him in Sevilla (during 'Iyāḍ’s first trip to al-Andalus in 498/1104-5), and again in Cordoba (during 'Iyāḍ's seven-months sojourn there in 507/1113-1114), and they continued to have written contact. ${ }^{85}$ 'Iyād mentions that both al-Ghazālī and Abū Bakr al-Ṭurțūshī (d. 520/1126) were among Ibn al'Arabī's teachers in the East, but he does not mention explicitly that Ibn al-'Arabī conveyed any of either's teachings to him. ${ }^{86}$ According to Maribel Fierro, both Ibn al-'Arabī and alTurțūshī were initially attracted to al-Ghazālî̀'s doctrine, and she suggests that there was some influence in their writings, although al-Ṭuttūshī had been unsuccessful in his attempt to meet al-Ghazālī. ${ }^{87}$ 'Iyāọ also had personal, written contact with al-Ṭurțūshī, who was from Tortosa in al-Andalus, but who travelled extensively in the East before settling in Alexandria where he lived most of his life. ${ }^{88}$ Ibn al-'Arabī first met al-Ṭurțūshī in Jerusalem going East. Then, coming back from Baghdād, Ibn al- ${ }^{c}$ Arabī met al-Ṭurțūshī again in Alexandria, and by then al-Ṭurțūshī had become more critical to al-Ghazālī’s teachings.

82 WeNSINCK, The Muslim Creed, 272-275.

83 Ibn al-'Arabī states in al- 'Awāșim min al-qawāṣim that he heard the Ihya $\bar{a}^{\text {' }}$ in Baghdad in Jumādà II 490 (= May 1097) (Muḥammad Ibn 'Abd Allāh IBN al-'ARABĪ, al-Naṣs al-kāmil li-Kitāb al-'Awāṣim min alqawāṣim, ed. 'Ammār Țālibī, Doha: Dār al-thaqāfa, 1992: 24). On the relationship between Ibn al'Arab̄i and al-Ghazālī, see Frank GrIFFEL, Al-Ghazālī's Philosophical Theology, Oxford: Oxford University Press, 2009: 62-71. George F. Hourani, thinks it most likely that the Ihy $\vec{a}$ ' was completed before this date (George F. HOURANI, "A Revised Chronology of Ghazālī's Writings," Journal of the American Oriental Society, 104.2 (1984): 289-302, 295-297).

84 The sources do not specify how he travelled from Fez to Seville, but Ceuta was the narrowest and consequently the most common point of transfer between the two coasts (al-MARRĀKUSHĪ, al-Mu'jam, 253).

85 Al-QĀḌ̄ 'IYĀḌ, al-Ghunya, 66-69; IBN 'IYĀḌ, al-Ta'rî̀f, 6-10.

86 Ibid., 64.

87 In "Opposition to Sufism," 185-186, FIERRO states that they tried to imitate the Ihyä, but in her Introduction to al-Ṭurțūshī's Kitāb al-Hawādith wa'l-bida' she is more suggestive of a certain influence ([Abū Bakr al-ṬurṬ̂̄SHĪ], Abū Bakr al-Ṭurțūšì (m. 520/1126): Kitāb al-Hawādit wa-l-bida ${ }^{c}=$ El libro de las novedades y las innovaciones, traducción y studio Maribel FIERRO, Madrid: Consejo Superior de Investigaciones Científicas, Instituto de Cooperación con el Mundo Árabe (Fuentes Arábico-Hispanas 14), 1993: 123).

88 Al-Ṭurțūshī never returned to the West (Fierro's Introduction to [al-ṬURṬūsHī], Kitāb al-Hawādit wa-lbida', 31).

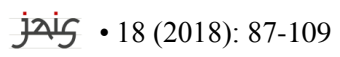


Ibn al-'Arabī later wrote at length about his meetings with al-Ghazālī and his teachings in several of his own books. In the Qānūn al-ta'wīl he describes their meeting and his own quest for knowledge, while in al-'Awāșim min al-qawāṣim he takes a more critical approach to al-Ghazālī's teachings, especially in epistemological issues. ${ }^{89}$ The 'Awāșim testify to the fact that Ibn al-'Arabī's criticism was founded on a thorough engagement with al-Ghazālī's work. In a discussion on the relationship between knowledge ('ilm) and activity ('amal), Ibn al-'Arabī holds that al-Ghazālì bases his statement on șüfi thought when he holds that knowledge is the fruit of activity (anna 'l-'ilm min thamarāt al-'amal). However, Ibn al'Arabī holds, knowledge is from activity before activity (inna 'l-'ilm huwa min al-'amal qabl al-'amal). Although none of the jurists or the theologians reject that the purification and cleansing of the heart is the aim of the $\operatorname{sharl}^{-} a$, Ibn al-'Arabī holds, the refuted idea is that this purification in itself will impress the disciplines of knowledge upon the heart. The refutation, he says, is a sound opinion as it is well founded both intellectually (dalil ' $a q l \bar{l}$ ) and in the $\operatorname{sharî}^{\complement} a$, as well as corroborated by experience (tajriba).$^{90}$ Ibn al- Arabī also criticized al-Ghazālī on account of his philosophical methodology, warned against uncritical reading of his work and specifically the points where he does not refer back to both intellectually acceptable and transmitted knowledge (naql). ${ }^{91}$ 'Iyāḍ does not mention in the Ghunya that he had read any of these works, but it may be reasonable to assume that he was exposed to these discussions in one way or another and that he perhaps even took part in them.

Al-Ṭurțūshì later wrote a critique of Ihy a ' 'ulūm al-dīn in the form of a letter to an unidentified Ibn Muẓaffar. ${ }^{92}$ Al-Ṭurțūshī held that al-Ghazālī’s reference to philosophy and the secret of destiny ( $\operatorname{sir}$ al-qadr) shows how he was influenced by the ikhwān al-safä and the battiniyya (in spite of his later explicit refutation of their methodology in al-Munqidh min al-dala $l$ ), and that his teaching on spiritual states ('ilm al-ahwāl) was too closely associated with the șūfìs. Even more gravely, al-Ṭurțūshī accused al-Ghazālī of lying about the Prophet, saying that he "knows of no other book of any knowledgeable standing on the face of the earth which lies about the Prophet more than this." ${ }^{, 93}$ Al-Ṭurtūshī then suggests that the Ihya $\bar{a}^{3}$ could be burned, comparing it to the burning of non-conforming leaves (suhuf) of the Qur'ān, as a preventive measure against it landing in hands not able to identify its poison (sumūmihi al-qātila). He remarks that most of the people who love the Ihy $\bar{a}^{\prime}$ are actually good people (șäliḥun), but lacking in knowledge. ${ }^{94}$ The statement is worded like an answer to a comment: "With regard to what you have mentioned about burning the book..." (wa-ammā mā dhakarta min ihrāq al-kitāb...). We do not know if the statement is an answer to an actual comment, or if it is here a conventional formula. In the

89 IBN al-'ARABī, Kitāa al-'Awāșim min al-qawāșim, cf. SERRANO, "Why Did the Scholars of al-Andalus Distrust al-Ghazālī?," 150-151; GRIFFEL, Al-Ghazālī, 66-67. Fierro holds that Ibn al-'Arabī also refuted al-Ghazāāī in his Sirāj al-murīdīn ([al-Ṭurț̄ishī], Kitāb al-Hawādith wa-l-bidac, 60).

90 IBN al-'ARABī, Kitāb al- 'Awāṣim min al-qawāșim, 16-18.

91 Ibid., 78, 80 and 92.

92 The letter is edited in GHRĀB, "Hawla iḥrāq al-murābițīn li-Ihyyā’ al-Ghazālī," 158-163.

93 Ibid., 160.

94 Ibid., 162-163. 
first case, it is possible that al-Ṭurțūshī had been asked to comment upon something that had already occurred just as much at it could be seeking his advice, or even a formal fatwà.

Al-Ṭurțūshī figures prominently in 'Iyāọ's Ghunya. 'Iyāọ conducted written communication with him and received written authorization from him for all his transmissions and works (kataba ilayya yuj̄̄zunī jamī a riwāyātihi wa-tașānīfih), but there is no mention of a reading or refutation of al-Ghazālī. ${ }^{95}$ However, al-Ṭurțūshī’s letter to Ibn Muzaffar sums up the main accusations presented against al-Ghazāli in the West, and these are points that may have come up in his communication with 'Iyâḍ as well. According to al-Subkī, this criticism predates the criticism of another of 'Iyạ̣̄'s contacts, al-Māzirīi. ${ }^{96}$ But al-Subkī held that whereas al-Ṭurțūshī's criticism was ridden by absurdities and wiswās, ${ }^{97}$ al-Māzirī raised a scholarly criticism to which al-Subkī replied in detail.

This Abū 'Abd Allāh al-Māzirī (d. 536/1141) is the last among 'Iyāḍ's contacts whom he reports in the Ghunya to have been in contact with al-Ghazālī. Kenneth Garden has argued that both al-Māzirī al-Dhakī (d. 510/1116) and Abū 'Abd Allāh al-Māzirī were among al-Ghazālī's critics, the first as an anonymous critic and the second as the writer of

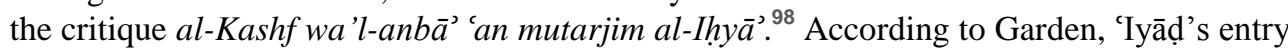
on al-Māzirī al-Dhakī in Tartīb al-madārik is the earliest and most detailed account of this Qayrawānī scholar's experiences in the East, where he found Mālikī teaching in decline. ${ }^{99}$ 'Iyāọ mentions al-Māzirī al-Dhakī's confrontation with al-Ghazālī, and this may put him among the group that was involved in a failed campaign against al-Ghazālī in Nīshāpūr around the year 500/1106-1107.

The other al-Māzirī, Abū 'Abd Allāh from Ifrīqiyya, was 'Iyāḍ's senior by some thirty years, and 'Iyāọ describes him as the most insightful of the Mālikī madhhab in his time, as well as a scholar of hadìth, medicine, mathematics and philology. 'Iyāḍ says he wrote to him from Mahdiyya with an ijāza for his book al-Mu'lim fi sharh Muslim, ${ }^{100}$ which 'Iyāḍ later expanded upon in his own Ikmāl al-mu'lim bi-fawā’id Muslim. According to 'Iyāḍ, Abū 'Abd Allāh al-Māzirī wrote an explanation of al-Burḥ̂an fì uṣūl al-fiqh, a work by alGhazālī's teacher al-Juwaynī (d. 478/1085), but 'Iyāẹ does not mention this work or any critique of al-Ghazālī among al-Māzirī’s books.

\footnotetext{
95 Al-QĀDī 'IYĀḌ, al-Ghunya, 64.

96 Al-SUBKī, Ṭabaqāt al-shāfí iyya, III: 445.

97 Ibid., III: 451.

98 Kenneth GARDEN, "al-Māzirī al-Dhakī: al-Ghazālī’s Maghribi adversary in Nishapur," Journal of Islamic Studies, 21.1 (2010): 89-107, 94. As noted by GARDEN (p. 104, footnote 61), there are a number of different variants of this title: al-Kashf wa-l-anba' (or inbä') 'alà (or 'an) al-mutarjam bi(or Kitāb) al-Ihya $\bar{a}^{2}$. See also GARDEN, The First Islamic Reviver. Apparently, even a third party, Abū 'Abd Allāh al-Māzirī al-Qurashī al-Iskandarī (d. 530/1135), was a critic of al-Ghazālī, but he is not relevant to the history of 'Iyāọ (GHRĀB, "Hawla iḥrāq al-murābiṭinn li-Ihyyä' al-Ghazālī," 137).

99 Al-QĀḌI 'IYĀḌ, Tartīb al-madārik, VIII: 101-103; cf. GARDEN, "al-Māzirī al-Dhakī," 97-102.

100 Al-QĀḌ̄ 'TYĀḌ, al-Ghunya, 65.
}

jais • 18 (2018): 87-109 


\section{Conclusion}

Al-Ghazālī was well known to 'Iyāẹ, as were the controversies surrounding his work. However, except for the few remarks on al-Ghazālī's misunderstanding concerning the Medianan ijm $\bar{a}^{c}$, 'Iyā do does not disclose much detail on his own involvement either with alGhazālī's work or in the controversies around his work. ${ }^{101}$ The allegations of 'Iyāḍ's direct intervention in the matter appear only in later sources. Al-Sha'rān̄̄ss (d. 973/1565) alTabaqāt al-kubrà and Ibn al-'Imād's (d. 1089/1679) Shadharāt al-dhahab fì akhbār man dhahab appear to be the earliest accounts to suggest that 'Iyād may have had a role in or even an opinion on the condemnation and burning of al-Ghazālī's $I h y \bar{a}$ ' or other of his works. Neither of the two authors provides any sources for their statements about 'Iyād. Moreover, they are separated not only by almost a century, but also by style, tone and the direct wording of their accounts. However, as we have seen, al-Dhahabī (d. 748/1348) had introduced 'Iyāḍ's name into the topic, if only as a reporter of the events.

Gómez-Rivas suggests that these allegations should be interpreted as "a gloss on 'Iyāḍ's perceived close ties to the pro-Mālikī Almoravid dynasty and his subsequent fate at the hands of the anti-Mālikī Almohads." ${ }^{102}$ As Safran holds, "The memory of the burning of alGhazâlī's book proved a powerful way for the Almohads to define their regime in opposition to the Almoravids." ${ }^{103}$ Sa'd Ghrāb also suggests that both the ban and the burning could be politically motivated allegations on part of the Almohads, with no historical basis, although he admits the possibility that the incident did take place. ${ }^{104}$ However, the available Almohad sources do not mention that 'Iyād had any role in the incidents, and it is questionable whether the North African ideological and historical context of the twelfth century was of primary concern to either al-Sha'rānī or Ibn al-'Imād, let alone to the even later al-Zabīdī (d. 1205/1790). Al-Zabīdī had many contacts from North Africa: official contacts, scholars, and people of learning and culture, some of whom were linked to the Sufi zāwiyas, ${ }^{105}$ and by al-Zabīdī's day, 'Iyāọ had already been fully restored as one of the seven saints of Marrakesh by the second Alaouite ruler, Maulay Ismāîll Ibn Sharīf (r. 1082-1139/1672-1727). ${ }^{106}$

Although the early historical sources do not present much detail on the subject, the strong objections in the West to al-Ghazālī's work were presumably common knowledge. 'Iyāḍ did refer to al-Ghazālī's misgivings regarding the Mālikī view of Medinan ijmā', but he does not seem to have been among his fiercest critics nor does he mention having read his work in his autobiographical catagolue, the Ghunya, 'Iyāḍ's last work to be completed less than a year before he died. Even if 'Iyāḍ had withheld a criticism of al-Ghazālī’s work

\footnotetext{
101 The only other reference to al-Ghazālī in the Tartīb is a reference to his book $\bar{A} d \bar{a} b a l-s u h b a$. Al-QĀḌ̄ 'IYĀḌ, Tartīb al-madārik, IV: 160.

102 GómEZ-Rivas, "Qāọī 'Iyāọ (d. 544/1149)," 327; ID., Law and the Islamization, 119.

103 SAFRAN,"The politics of book burning," 155.

104 GHRĀB, "Ḥawla iḥrāq al-murābiṭin li-Ihyā̄a al-Ghazālī," 151, 155.

105 Reichmuth, The World of Murtadā al-Zabīdī, 182-189.

106 Mariette ERRAZKI-VAN BEEK, "The Seven Saints of Marrakesh: Tales and Traditions," The Arabist: Budapest Studies in Arabic, 9-10 (1994): 211-224.
} 
in order to strengthen his case with the new rulers, there was certainly no reason why he should have refrained from reading and engaging with his work. The concrete incidents of condemnation and burning or the order to burn his work in the early twelfth century were fairly known to the later scholarly community, but not necessarily in detail. Thus, until further historical sources potentially may shed some more light on the issue, 'Iyāḍ's alleged role in condemning, outlawing or burning al-Ghazālī's work Ihy à' 'ulüm al-dìn must be understood as a mix-up of historical facts, anecdotes and overly interpretative assumptions, chiefly motivated by concerns not related to 'Iyāḍ’s work, biography or legacy.

\section{References}

Arabi, Oussama, David Stephan Powers, and Susan Ann SPeCtorsky (eds.). 2013. Islamic Legal Thought: A Compendium of Muslim Jurists. Brill, Leiden.

Ávila NAvarro, María Luisa, and María Isabel Fierro Bello (eds.). 1999. Biografías almohades I. Consejo Superior de Investigaciones Científicas, Madrid.

BEnNison, Amira K. 2016. The Almoravid and Almohad Empires. Edinburgh: Edinburgh University Press.

CABANElAS, Dario. 1952. "Notas para la historia de Algazel en España." al-Andalus, 17.1: 223-232.

CASEwIT, Yousef. 2017. The Mystics of al-Andalus: Ibn Barrajan and Islamic thought in the twelfth century. Cambridge University Press, Cambridge.

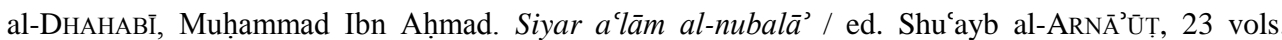
Beirut: Mu'assasat al-Risāla, 1985.

DE JoNG, Frederick, and Bernd RADTKE (eds.). 1999. Islamic Mystisicm Contested: Thirteen Centuries of Controversies and Polemics. Brill, Leiden.

EGGEN, Nora S. 2018. "In defence of the Prophet, and of scholarly tradition: al-Qāḍī 'Iyāḍ̂'s al-Shifāa bi-ta'rîf huqūq al-muștafà - The Healing in Knowing the Rights of the Chosen One.” In MoE (et al., eds.) 2018 (forthcoming).

El Hour, Rachid. 2000. "The Andalusian Qāộ̄ in the Almoravid Period: Political and Judicial Authority." Studia Islamica, 90: 67-83.

ERraZKI-VAN BEEK, Mariette. 1994. "The Seven Saints of Marrakesh: Tales and Traditions." The Arabist: Budapest Studies in Arabic, 9-10: 211-224.

FAHD, Badrī Muhammad. 1980. "Kitāb al-shifā bi-tárīf ḥuqūq al-mușṭafà.” al-Manāhil, 19: 488-535.

FIERro, Maribel. 1997. "La religion.” In VigerUA MoLínS (ed.) 1997: 483-495.

—. 1999. "Opposition to Sufism in al-Andalus.” In DE Jong \& RADTKE (eds.) 1999: 174-206.

FLETCHER, Madeleine. 1997. "Ibn Tūmart's teachers: the relationship with al-Ghazālī." al-Qanțara, 18.2: 305-330.

FromHERZ, Allen J. 2010. The Almohads: The Rise of an Islamic Empire. I.B. Tauris, London \& New York.

GARDEN, Kenneth. 2010. “al-Māzirī al-Dhakī: al-Ghazālī’s Maghribi adversary in Nishapur.” Journal of Islamic Studies, 21.1: 89-107.

-.2014. The First Islamic Reviver: Abū Hāmid Al-Ghazālī and His Revival of the Religious Sciences. Oxford: Oxford University Press.

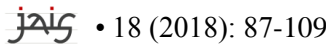




\section{A book burner or not? Revisiting al-Qāḍī 'lyāọ}

García-Arenal, Mercedes. 2006. Messianism and Puritanical Reform: Mahdīs of the Muslim West. Brill, Leiden.

al-GHAZĀLĪ, Abū Ḥāmid Muḥammad Ibn Muḥammad. Ihyyà 'ulūm al-dīn, 5 vols. Beirut: Dār al-Kutub al-'Ilmiyya, 2001.

GHRĀB, Sa'd. 1983. "Hawla iḥrāq al-Murābiținn li-Ihyǟ al-Ghazālī." Actas del IV Coloquio HispanoTunecino. Madrid: Instituto Hispano-Árabe de Cultura, 1983: 133-163.

Gómez-Rivas, Camilo. 2013. "Qāạī 'Iyāọ (d. 544/1149).” In Arabi / Powers / SPeCtorsky (eds.) 2013: 323-338.

- 2014. Law and the Islamization of Morocco under the Almoravids: The Fatwās of Ibn Rushd alJadd to the Far Maghrib. Brill, Leiden.

GRIFFEL, Frank. 2009. Al-Ghazālī's Philosophical Theology. Oxford: Oxford University Press.

HourANI, George F. 1984. “A Revised Chronology of Ghazālī’s Writings.” Journal of the American Oriental Society, 104.2: 289-302.

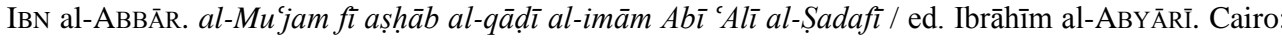
Dār al-Kitāb al-Mișrī / Beirut: Dār al-Kitāb al-Lubnān̄̄, 1989.

IBN al-Ạ̣mAR, Ismāê̄1. 1972. Buyūtāt Fās al-kubrà. Rabat: Dār al-Manșūr lil-ṭibāca wa'l-warāqa.

IBN al-'ARABĪ, Muḥammad Ibn 'Abd Allāh. al-Nașs al-kāmil li-Kitāo al-'Awāṣim min al-qawāṣim / ed. 'Ammār TĀLIBĪ. Doha: Dār al-Thaqāaa, 1992.

— 1970. Risālat rūḥ al-qudus fì muḥāsabat al-nafs wa'l-mabādi’ wa'l-ghāyāt fì-mā tatadammanuhu hurūf al-mu'jam min al-'ajā'ib wa'l-āyāt, ed. 'Izzat HusRIYYA. Damascus: Maṭa'at al-'Ilm.

IBN BASHKUWĀL. Kitāb al-șila / ed. Ibrāhīm al-ABYĀRĪ, 3 vols. Cairo: Dār al-Kitāb al-Mișrī / Beirut: Dār al-Kitāb al-Lubnānī, 1989.

IBN FARHūN. al-Dībāj al-mudhahab fì ma'rifat acyān 'ulamā’ al-madhhab / ed. Muhammad alAḥmadī ABū 'L-NŪR, 2 vols. Cairo, Dār al-turāth, 1972.

IBN al-'IMĀD, 'Abd al-Ḥayy Ibn Aḥmad.. Shadharāt al-dhahab fi akhbār man dhahab / eds. 'Abd al-Qādir al-ARNĀ'ŪṬ and Maḥmūd al-ARNĀ'ŪṬ, 10 vols. Damascus \& Beirut: Dār Ibn Kathīr, 1986-1993.

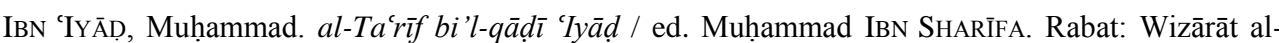
Awqāf wa'l-shu'ūn al-islāmiyya, 1982.

—. Madhāhib al-hukkām fì nawāzil al-ahkām / ed. Muhammad IBN SHARĪFA. Beirut: Dār al-Gharb al-Istāmī, (1990) 1997.

- 1998. al-Hukkām fì nawāzil al-ahkām = La actuación de los jueces en los procesos judiciales (Fuentes arábico-hispanas 22), [transl.] Delfina SERRANo. Madrid: Agencia Española de Cooperación Internacional.

IBN KHALliKĀN. Wafayāt al-a yān wa-anbāa' abnāa al-zamān / ed. Yūsuf 'Alī ṬAWĪL and Maryam Qāsim ȚAWīL, 6 vols. Beirut: Dār al-Kutub al-'Ilmiyya, 1998.

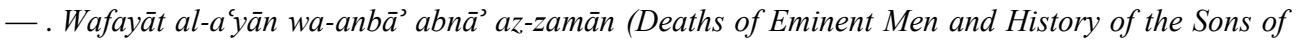
the Epoch) / transl. MAC GUCKIN DE SLANE, 4 vols. Beirut: Librarie du Liban, 1970.

IBN KHĀQĀN. Qalāìd al- 'iqyān wa-mahāsin al-a yāan / ed. Husayn Yūsuf KHARYŪSH. Zarqā’ (Jordan): Maktabat al-manār, 1989.

IBN al-KHAṬīB. al-Ihāṭa fì akhbār Gharnāṭa / ed. Būziyānī al-DARĀJī. Algiers: Dār al-Amal li'ldirāsāt, 2009.

[IBn TŪMART. Kitāb a'azz mā yutlab.] Le livre de Mohammed Ibn Toumert / ed. I. GoldZIHER. Alger: Imprimerie Orientale Pierra Fontana.

IBN ȚUMLŪs, Yūsuf. al-Madkhal li-șinăcat al-manțiq / ed. Mīkāīl Asīn. Madrid: al-Maktaba alAbīriqa, 1916. 


\section{Nora S. Eggen}

LAGARDÈRE, Vincent. 1986. "La haute judicature à l'époque almoravide en al-Andalus." al-Qanțara, 7.1: $135-228$.

LeVI-ProvençAL, E. 1955. "Le titre souverain des Almoravides et sa légitimation par le califat 'abbaside." Arabica, 2: 265-280.

MaCDONALD, Duncan B. 1899. "The Life of al-Ghazzālī, with Especial Reference to His Religious Experiences and Opinions.” Journal of the American Oriental Society, 20: 71-132.

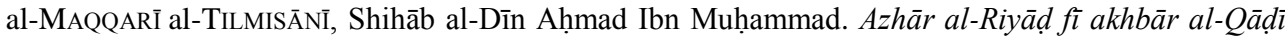
'Iyāẹ / ed. Muṣtafà al-SAQQÀ, Ibrāhīm al-ABYĀRĨ and 'Abd al-Ḥafĩz SHiBLī, 5 vols. Cairo: Maṭū̄ât Lajnat al-ta'līf wa'l-tarjama wa'l-nashr, [1939-1942].

al-MARRĀKUSHī, 'Abd al-Wāhìid. al-Mu'jam fì talkhīṣ akhbār al-Maghrib / ed. Khalīl 'Imrān alMANȘŪR. Beirut: Dār al-Kutub al-'Ilmiyya, 1998. - Transl. in E. FAGnAn, Histoire de l'Afrique et de l'Espagne intitulée al-Bayano l-Mogrib. Algiers: Imprimerie Oriental P. Fontana, 1901-1904.

—. Nuẓum al-jumān li-tartīb mā salafa min akhbār al-zamān / ed. Maḥmūd 'Alī MAKKĪ. Beirut: Dār al-Gharb al-Islāmī, 1990.

Moe, Christian, Kari Vogt, Lena Larsen, and Khalid Muhammad Masud (eds.). [2018, forthcoming]. Freedom of Expression in Islam: Challenging Apostasy and Blasphemy Laws. I.B. Tauris, London.

MU’NIS, Ḥusayn. 1955. "Nuṣūṣ siyāsiyya 'an fatrat al-intiqāl min al-murābițīn ilà 'l-muwaḥhidīn." Revista del Instituto Egipcio de Estudios Islámicos, 3.1: 97-140.

al-QĀḌ̄ 'IYĀḌ. al-Ghunya: Fihrist shuyūkh al-Qāẹ̄ 'Tyād / ed. Māhir Zuhayr JARRĀR. Beirut: Dār alGharb al-Islāmī, 1982.

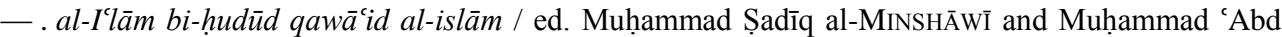
al-Raḥmān `ABD AL-MuN'ì. Cairo: Dār al-Faḍīla, 1995.

- Tartīb al-madārik wa-taqrīb al-masālik li-ma'rifat a' lām madhhab Mālik. 8 vols. / ed. Muhammad Bin Tāwīt al-Ṭ̂ANJī (vol. I), 'Abd al-Qādir al-ṢAḤRĀWĪ (vols. II-IV), Muḥammad IBN SHARīFA (vol. v), and Sa'īd Aḥmad A'RĀB (vols. VI-VIII). Rabat: Wizārāt al-Awqāf wa'l-Shu'ūn alIslāmiyya, 1983.

ReICHMUth, Stefan. 2009. The World of Murtadāa al-Zabìdī (1732-91): Life, Networks and Writings. E.J. Gibb Memorial Trust, Cambridge.

SAFRAN, Janina M. 2014. "The politics of book burning in al-Andalus." Journal of Medieval Iberian Studies, 6.2: 148-168.

SERrAno RuANO, Delfina. 2006. "Why Did the Scholars of al-Andalus Distrust al-Ghazālī? Ibn Rushd al-Jadd's Fatwā on Awliyä’ Allāh.” Der Islam, 83.1: 137-156.

SERRANO, Delfina. 1999. "Los Banū 'Iyāẹ (de la caída del imperio almorávid a la instauración de la dinastía nazarí).” In Ávila NAvarro \& Fierro Bello (eds.) 1999: 351-406.

- .2000. "Legal Practice in an Andalusī-Maghribī Source from the Twelfth Century CE: The Madhāhib al-ḥukkām fĩ nawāzil al-ạ̣kām.” Islamic Law and Society, 7.2: 187-234.

al-SHA ${ }^{C} \mathrm{RĀNI},{ }^{\prime}$ Abd al-Wahhāb. Al-Ṭabaqāt al-kubrà (= Lawāqih al-anwār al-qudsiyya fí manāqib al'ulamā’ wa'l-șūfiyya) / ed. Aḥmad 'Abd al-Raḥmān al-SĀYıH and Tawfíq 'Alī WAHBA, 2 vols. Cairo: Maktabat al-Thaqāfa al-Dīniyya, 2005.

al-SuBKī, Tāj al-Dīn 'Abd al-Wahhāb. Țabaqāt al-shāfíiyya al-kubrà / ed. Muștafà 'Abd al-Qādir 'AṬ̂̄, 6 vols. Beirut: Dār al-Kutub al-'Ilmiyya, 1999.

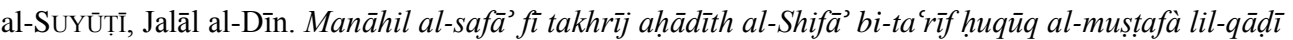
'Iyāẹ. Beirut: Mu’assasat al-kutub al-thaqāfiyya; Dār al-Jinān, 1988.

al-TĀDILİ, Yūsuf Ibn Yahyà Ibn al-Zayyāt. al-Tashawwuf ilà rijāl al-tașawwuf wa-akhbār Abì 'l-

jais • 18 (2018): 87-109 


\section{A book burner or not? Revisiting al-Qāḍī 'lyāọ}

'Abbās al-Sabtī / ed. Aḥmad TAWFīQ. Rabat: Kulliyyat al-Ādāb wa'l-'Ulūm al-Insāniyya, 1984.

[al-ṬuRṬūshī, Abū Bakr]. Abū Bakr al-Ṭurțūšs̄ (m. 520/1126): Kitāb al-Hawādit wa-l-bidac = El libro de las novedades y las innovaciones / Traducción y studio Maribel FIERRO. Madrid: Consejo Superior de Investigaciones Científicas, Instituto de Cooperación con el Mundo Árabe, 1993 (Fuentes Arábico-Hispanas; 14).

Urvoy, Dominique. 1993. "Le Manuscrit Ar. 1483 de l'Escurial et la Polemique contre Gazālī dans al-Andalus.” Arabica, 40.1: 114-119.

Vigerua Molíns, María Jesús (ed.). 1997. El retroceso territorial de al-Andalus. Almorávides y almohades: Siglos XI al XIII. Espasa Calpe, Madrid.

VigueRA, María J. 1977. "Las cartas de al-Gazālī y al-Ṭurțūši al soberano almorávid Yūsuf b. Tāšufinn.” al-Andalus, 42.2: 341-374.

al-WANSHARĪSĪ, Aḥmad Ibn Yahyyà. Mícyār al-mu'rib wa'l-jāmic al-mughrib 'an fatāwà ahl Ifrīqiyā wa'l-Andalus wa'l-Maghrib / ed. Muhammad HịJJī, 13 vols. Fez: Wizārat al-Awqāf wa'l-Shu'ūn al-Islāmiyya lil-Mamlaka al-Maghribiyya, 1981.

Wensinck, A. J. 1932. The Muslim Creed: Its Genesis and Historic Development. Cambridge: Cambridge University Press.

VizCAínO, Juan M. 1991. "Las obras de zuhd en al-Andalus." al-Qantara, 12.2: 417-438.

WINTER, Michael. 1982. Society and Religion in Early Ottoman Egypt: Studies in the Writings of 'Abd al-Wahhāb al-Sha rāāni. Transaction Books, New Brunswick.

WyMANN-LANDGRAF, Umar F. Abd-Allah. 2013. Mālik and Medina: Islamic Legal Reasoning in the Formative Period. Leiden: Brill.

al-ZABĪDĪ, Murtaḍà. Ithāaf al-sāda al-muttaqīn bi-sharh Ihyā' 'ulūm al-dīn, 13 vols. Miṣr: al-Maṭba'a al-Maymaniyya, 1311 [=1893-4].

(c) Nora S. Eggen, University of Oslo / Norway

\n.s.eggen@teologi.uio.no 